\title{
BIOMASS POTENTIAL ENERGY AS FUEL FOR AUTOMOTIVES -AN OVERVIEW
}

\author{
Palaniswamy E. ${ }^{1}$, and Manoharan N. ${ }^{2}$ \\ 'Department of Mechanical Engineering, EIT, Erode \\ ${ }^{2}$ Sathyabama University, Jeppiar Nagar, Rajiv Gandhi Road, Chennai, India \\ E-mail : prof.eps@gmail.com
}

\begin{abstract}
In present context of cleaner environment and conservation of petroleum fuels, the biofuels are being looked into with renewed interest. India has high potential of producing liquid biofuels like ethanol and bio-diesel. Today fuel-ethanol accounts for roughly two third of the world ethyl alcohol production. India is the fourth largest producer of ethanol in the world, yet it has not been able to utilize even one percent of this production as fuel for vehicles. If the ethanol can be produced efficiently from vegetation then the production of green house gases ( $\mathrm{GHG}$ ) emitted from vehicles can be reduced effectively. The vegetation uses $\mathrm{CO}_{2}$ gas and produces $\mathrm{O}_{2}$ just the reverse of the combustion process. Ethanol blended fuel helps to minimize $\mathrm{HC}, \mathrm{NOx}, \mathrm{CO}$, non -methane organic gas (NMOG), soot particles and toxics.
\end{abstract}

KEYWORDS : Biomass, Green house gases, biofuels

\section{INTRODUCTION}

Supply of affordable energy to all strata's of society is at the top of the development agenda of the most developing countries, as otherwise these societies have almost no chance of escaping from the poverty trap. However, higher energy consumption brings with it the problem of environmental pollution. Petroleum- based fuels are highly polluting the mother earth. India imports about $70 \%$ of its petroleum consumption. Security of even this supply is not guaranteed as most of India's import is from the Gulf countries that are most of the time under political turmoil. By 2010 this percentage is likely to increase to $82 \%$. The higher fossil petroleum cost will affect our India by way of inflation. This will affect the livelihood of nearly $80 \%$ of the country's population since they dependent on agriculture. Thus for India, like many other nations in the world, national security for energy supply, rural employment and concern for the environment are the main driving forces for the search of a renewable and clean source of energy for the transportation. Bio-fuels are one of the answers of this search.

Govt. of India has been working to develop a road map for bio-fuel production. In January 2006, it mandated the use of $5 \%$ ethanol in the gasoline to be marketed in 9 states. Depending upon the availability of ethanol, the rest of the country will be covered under this scheme. This mandate was issued by the petroleum ministry of India after two years of extensive field work at 5 pilot centres across the country. SIAM (Society of Indian Automotive Manufactures) and its members and oil companies participated in these trials. Right now trials for $10 \%$ ethanol blends are under progress. In India, the ratio of diesel fuel to gasoline fuel is of the order of 7:1, a highly skewed situation. Thus the country needs to replace diesel fuel by alterative fuels. Use of ethanol-diesel blends and biodiesel are the two immediate possibilities.

\section{REQUIREMENTS FOR INTRODUCING A NEW AUTOMOTIVE FUEL}

In 1904, Henry Ford declared that ethanol would be the fuel of the future. However, with the invention of tetraethyl-lead as an octane booster, the oil companies took a different route by using TEL in gasoline formulations. As would be clear from Table 1, it took us nearly 40 years to understand and accept the health effects of using lead in gasoline. India now uses lead free gasoline all over the country but many Asian and African countries still continue to use leaded gasoline. Then in 1970s, increased amount of aromatics was used to ethanol octane. Again it took another 20 years to realize that even this option had lot of problems in that extra aromatic content caused more combustion chamber deposits and hence, increase in harmful engine emissions. Almost at the same time, oxygenates were introduced but picked up only recently.

Table-1. Gasoline - Ethanol fuel properties

\begin{tabular}{|l|c|c|}
\hline Details & Gasoline & Ethanol \\
\hline Specific calorific valve $(\mathrm{KJ} / \mathrm{kg})$ & 43,900 & 26,700 \\
\hline Octane number & 91 & 108 \\
\hline Latent heat of vaporisation $(\mathrm{KJ} / \mathrm{kg})$ & 502 & 903 \\
\hline Ignition temperate & 220 & 420 \\
\hline Stoic isometric AJF rabio & 14.5 & 9.2 \\
\hline
\end{tabular}

\section{ETHANOL AND GASOLINE BLEND}

The alcohol program in Brazil, the world's largest programme of tapping a renewable energy source, has been in operation for more than 16 years and has proved to be than resilient and successful. The cost of production of 
alcohol has been lowered through continuous technical improvements and this trend is undoubtedly to be accelerated by the new technology i.e. biomass integrated gasoline/gas turbine technology (BIG/GT) for cogeneration of electricity with bagasse. Ethanol can be used as a vehicle fuel in the petrol engine with certain modifications including engine management changes and material substitution (some metal alloys and polymers) in the fuel system. Volumetric efficiency will be increased due to ethanol's high heat of evaporation, but to achieve the increase in thermal efficiency the compression ratio should be raised inline with its high octane rating. This can lead to an efficiency increase of about $15 \%$ over a petrol engine for ethanol as petrol substitute.

Lubricants are to be formulated specifically for the use of ethanol in SI engine. Anticorrosion additives may also help to reduce engine wear. The addition of petrol at $15 \%$ to ethanol (E85 blend) has an ability to improve lubricity and reduce wear in addition to improving cold starting and cold derivability. Ethanol is used in blend with gasoline at $10-85 \%$ in volume (E10-E85) which contains about $3.5 \%$ weight of oxygen. Usually the blends are obtained by 'splash' blending the ethanol with unleaded gasoline. As oxygenater the ethanol fuel enhances the combustion of gasoline, resulting in more efficient burn and greatly reduced emissions. It helps to minimize all pollutants including $\mathrm{HC}, \mathrm{CO}, \mathrm{NOx}$, soot particles and toxics.

Table-2. Emission profile of Ethanol- Gasoline

\begin{tabular}{|c|c|c|}
\hline Parameters & $\begin{array}{c}\text { \% of emission reduction with } 10 \% \\
\text { Ethanol }\end{array}$ & $\begin{array}{c}\text { \% of emission reduction with } 20 \% \\
\text { Ethanol }\end{array}$ \\
\hline HC & Neutral & Neutral \\
\hline CO & $-20 \%$ & $-28 \%$ \\
\hline NOx & $-4 \%$ & $-6 \%$ \\
\hline
\end{tabular}

The recent crisis in global oil price hike (now above $\$ 135$ per barrel) has prompted the Indian government to take measures to control high import bills and raising oil pool deficit. In India, the current installed capacity of ethanol production can easily meet the gasoline demand of the transport sector by $10 \%$ blend. Converting sugarcane juice directly to ethanol can increase ethanol production significantly. At present the Government has not given much priority in implementing the ethanolGasoline blended fuel. It is essential that the efforts are to be directed to assess the potential of ethanol in automobiles on an urgent basis.

\section{ROLE OF GOVERNMENT IN ETHANOL PRODUCTION}

Adoption of new ethanol production technologies and development of new automobile engine sales and service networking, financing etc need a dedicated programme and policies for its introduction in the transport sector. The widespread use of ethanol leads to higher sugarcane productivity, rural employment and its purchasing power and growth in Industry. The policy related issues include the role of state and central government agencies, ethanol availability, supply, mixing, distribution and its use in automobile engines. In India the molasses based distilleries mainly supply ethanol which is largely produced in state such as UP, AP, Gujarat and Karnataka. Sugar and distillery industries are complementary to each other as major players in the ethanol sector. The Government has therefore to play its critical role in defining policies favouring these industries. There are no technical barriers to prevent the widespread introduction of ethanol since there is very good scope for converting sugarcane directly into ethanol. Around 67 million litres of ethanol per million ton sugarcane can be produced directly from sugarcane juice.

\section{ENGINE REQUIREMENT}

Ethanol properties have led to the development of modified engines (E-20 to E-100) for the Ethanol-Gasoline mixture in Brazil. The main fuel properties necessitating engine changes with respect to the conventional gasoline engine are shown in Table 1. With the intension to limit the corrosive behaviour of ethanol and the formation of inorganic deposits on internal engine surfaces some technical modifications are made in engine management.

\section{Combustion process parameters}

w Higher compression ratios (12:1 instead of 8.1:1)

* Larger fuel tank volumes By 20\%

w Colder spark plugs

w Specially designed Multi Port fuel injection system (MPFI) in the case of Petrol Engine, CRDI system in Diesel Engine.

w Automatic cold starting system (Starting the engine with gasoline injection)

w Heated air inlet

w Electric heater warm up system

\section{Measures to prevent corrosion due to ethanol fuel}

w Tin coated fuel tanks

w Tin coated filling nozzle

w Fuel lines: Pump to tank polyamide made up of nylon. Pump to carburettor: Nitrile rubber 
w Electroless nickel coated carburettor surface or MPFI Injectors

w Cadmium nickel - dichromate coated fuel pump.

w Stainless steel coated cylinder head gasket

w Hardened stellite valve materials and valve seats

\section{E-DIESEL}

Ethanol-diesel blends, popularly called as E-diesel, are still in the experimental stage. Induction of two fuels separately (duel-fuel approach) in not considered attractive. In E-Diesel, up to $15 \%$ volume of fuel grade ethanol (ASTM 4806) along with 0.5 to $5 \%$ co-solvent is used to create suitable ethanol-diesel micro-emulsion. All products are splash blended. Cetane improvers are used to compensate for the loss of cetane value. Lubricity additives are used to regain loss of lubrication inpumping system due to ethanol. Anti-corrosion additives are also needed to combat the corrosive nature of the polar compounds in ethanol. Blending of ethanol in diesel fuel has several problems that still need to be resolved before E-Diesel can be used commercially.

\section{E-Diesel problems in Cl engines}

- Vapour lock characteristics of the fuel are affected due to addition of ethanol.

- Phase stability required under all operating conditions of temperature, pressure, humidity and altitude.

- Fuel tank has to be designed to avoid explosion risk

- Due to the corrosive nature of ethanol, material compatibility and durability of the engine and fuel system components are need to be upgraded

- Acceptance of engine and fuel injection system by OEMS with warranty on operating with E-Diesel

- Affinity of ethanol to water can cause severe fuel system problems like corrosion, phase separation etc

- Establishment of E-Diesel standards

\section{CONCLUSIONS}

- The private and public sector participation can produce favourable condition for better ethanol market

- Cost of ethanol has to be lowered at global level to promote clean global environment

- The production cost of ethanol will be in the declining trend as agricultural and industrial technologies are improved such as mechanised planting and harvesting seeding technologies, genetic engineering etc.

- The development of technology for sugarcane production and processing into sugar and ethanol would help for creation of more rural jobs with modest investment cost

- E-Diesel will provide a sustainable environmental friendly solution that does not deplete fossil fuel reserves with very high potential for rural employment

\section{REFERENCES}

[1] Report of the committee on Development of Biofuels: Planning commission, April 16, 2003

[2] Moses, C.A.T.W. Rayan and W.E. Likos, "Experiments with Alcohol - Gasoline fuel blends in SI Engine", VI International Symposium on Alcohol Fuel Technology, Guarija, Brazil, 1980

[3] Letcher, T.M. "Ethanol Blends for Diesel Engines", South Africa Journal of Science, 79 (i) Pp 4-7, 1983

[4] Hashmota, I., H.Natashima, k.Komi yama, Y.Meeda, "Diesel Ethanol fuel blends for heavy duty diesel Engine - A study of performance and durability", SAE Technical Paper 820497, 1982

[5] Sarkkinen K. Alcohol for Automobiles, Indian Auto 1997; 7(4): Pp20-21

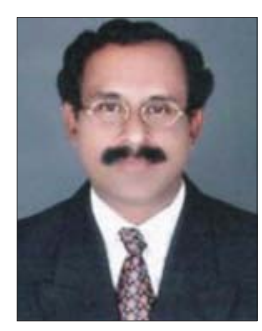

Mr. Palaniswamy .E is Professor, in the Department of Mechanical Engineering, EIT, Erode. He obtained his M.E. Degree in 1982 from MIT, Anna University, Chennai. He is currently working towards Doctoral Degree in Biodiesel Emissions. He has published 12 papers in National and International Conferences.

Published 4 research papers in leading Journals. His area of interest is CAD \& CAM, Current Trends in Automobiles, Education Management, etc. He is a life member of IE and ISTE. 